\title{
THE "Re-COLONISING" OF PITCAIRN
}

\author{
Sue Farran*
}

The criminal trials of Pitcairn islanders on charges of rape and sexual assault have attracted considerable media notoriety and some academic comment in New Zealand and elsewhere. However question marks remain; not as regards the guilt or otherwise of the accused but in respect of the means whereby they were brought to trial. In particular the legal reasoning used to exercise imperial rule over Pitcairn and the embroilment of New Zealand in the "Pitcairn case" deserves scrutiny. This article critically considers how the courts, including the Privy Council, determined that Pitcairn Islanders were British subjects and therefore within the exercise of Her Majesty's prerogative powers and which law was applicable to them, and the consequences of that process, both for Pitcairn as well as New Zealand.

\section{INTRODUCTION}

This article considers a recent example of the exercise of the prerogative powers of the British sovereign which demonstrates that certain legal features of British colonialism remain intact and of contemporary relevance in the Pacific region. It critically analyses the arguments developed for asserting British control over Pitcairn, an island which lies midway between Peru and New Zealand, and the direct consequences that flowed from that for the people of Pitcairn and, incidentally, for New Zealand.

The catalyst for these events was the criminal case of Christian and Others $v$ The Queen. ${ }^{1}$ While the gravity of the offences should not be overlooked, the steps taken to prosecute these accused have been extraordinary, demonstrating aspects of imperial rule which one might have thought had long since fallen into disuse. For this reason, not only does the Pitcairn case demonstrate how subjects in overseas territories are brought within the scope of British jurisdiction

* Senior Lecturer, University of Dundee; Visiting Lecturer, University of the South Pacific.

** Case references are taken from Paclii (www.paclii.org) unless otherwise indicated.

1 Christian and Others $v$ The Queen [2006] UKPC 47. There is a sequence of cases leading to the Privy Council ruling. These are Re Complaints made by the Public Prosecutor against 9 named defendants (10 April 2003) Magistrate's Court Pitcairn Islands Magistrate Cameron; $R v$ Seven Named Accused (19 April 2004) Trials No 1-55/2003 (Pit); The Queen v 7 Named Accused [2004] PNSC 1; Christian v The Queen [2004] UKPC 52; Christian v R (No 2) [2006] PNCA 1. 
and thereby may remain subjugated to British control in the twenty-first century, but it also illustrates how former colonies might be prevailed upon to facilitate this process.

\section{THE PITCAIRN CASE}

Apart from its notoriety as the refuge of the mutineers of the British ship HMS Bounty, Pitcairn has been largely ignored and neglected by Britain for the last two hundred years. In 1999 however, this small Pacific place made international headlines when it emerged, as a result of investigations headed by British police, ${ }^{2}$ that a number of incidents of sexual abuse of women and underage girls had been taking place over an extended period of time without criminal conviction. This was to be remedied. Nine men were initially charged: seven residents of Pitcairn and two living abroad. Six were convicted, either on counts of rape or indecent assault or both. Sentences ranged from community service to imprisonment.

Two key and fundamental issues arose in pre-trial and trial proceedings. First, were Pitcairn Islanders British subjects and therefore within the exercise of Her Majesty's prerogative powers; and secondly, if they were, did the law under which they were charged apply to them?

These questions, or various aspects of them, were raised and considered prior to trial and during the hearings of the Supreme Court and Court of Appeal of Pitcairn. The Privy Council however, declined to hear argument on either the question of whether the people of Pitcairn are British subjects, or whether Pitcairn is a British territory. Had the Privy Council been less willing to accept that Pitcairn was a British settlement there might have been greater consideration of the possible relevance of another recent decision in England concerning the scope of judicial review of the exercise of prerogative powers. ${ }^{3}$ As it was, Lord Hoffman, who delivered the advice of the Privy Council, stated: ${ }^{4}$

[T]he legal status of the island as a British possession is concluded by successive statements of the executive, starting with the direction of the Secretary of State in 1898 and ending with the making of the 1970 Order in Council.

Not only is this judicial acceptance of executive statement very uncritical, but this brief summary does little to indicate the historic relationship of Britain with this small island and could suggest, quite misleadingly, that Pitcairn had been nurtured as a British Settlement for several

2 Initially two complaints were brought to the attention of a single British police officer based on the island in 1999. This led to a much larger scale investigation called Operation Unique culminating in prosecutions in 2003.

3 The Queen on the Application of Louis Olivier Bancoult $v$ The Secretary of State for Foreign and Commonwealth Affairs [2006] EWHC 1038 (the Chagos Islands case), recently upheld on appeal in $R v$ Secretary of State for the Foreign and Commonwealth Affairs (On the Application of Bancoult) [2007] EWCA Civ 498.

$4 \quad$ Christian and Others $v$ The Queen [2006] UKPC 47 para 9 Lord Hoffmann. 
centuries. Such is not the case. In fact it is the sudden and excessive interest that Britain has shown in the island in the last seven years which raised questions about the relationship between the island and Britain. This article therefore examines the fundamental premises on which the Privy Council proceeded, specifically: whether the people of Pitcairn are British subjects; the nature of British control over Pitcairn; and whether the Act under which the accused were charged was part of the law of Pitcairn.

\section{A Are the People of Pitcairn British Subjects?}

In order to bring the accused within British jurisdiction it was necessary to establish that Pitcairn islanders were British subjects who remained subject to imperial law. Establishing this necessarily entailed a consideration of the history of Pitcairn and, more importantly, an interpretation of that history which arrived at a satisfactory conclusion. History of course is subject to a variety of interpretations, depending on the agenda of the interpreter. The history of colonial settlement has from time to time been subject to scrutiny and reinterpretation, hence the importance of this exercise in the case of Pitcairn. ${ }^{5}$

When the mutineers arrived on the island they were fleeing the reach of English law. They had committed mutiny, desertion and treason. One of the early arguments raised by the Pitcairn Islanders brought for trial was that they were not British subjects. The basis for this claim was that by their actions the mutineers had severed their allegiance to the Crown. Further, even if the original mutineers remained British subjects, their children were illegitimate and under the laws applicable at the time took their mothers' nationality, which was Tahitian. ${ }^{6}$

The Supreme Court rejected these claims on the grounds that, first, the mutineers were British subjects by birth and this could not be changed by their own acts while such breaches of allegiance remained pardonable by the Crown. Although none of the Pitcairn mutineers were ever pardoned, some others who had remained on Tahiti were ultimately pardoned. In effect, therefore, although the mutineers on Pitcairn were "fugitives from the Laws of England" ${ }^{7}$ the very fact that they were never arrested and brought to justice meant that they remained subject to British laws. Indeed, it was held that an act of treason did not remove a subject from the protection of the British Crown unless the subject has renounced this protection. Authority for this proposition was the case of "Lord Haw Haw", the Nazi propagandist of the Second World War who was convicted of high treason. ${ }^{8}$ The case is distinguishable. "Lord Haw Haw" was an alien holding a British passport. The mutineers

5 Compare for example the dicta of Prendergast CJ in Wi Parata v Bishop of Wellington (1877) 3 NZ Jur (NS) 72, 77 and the apology of the Crown in the Waikato Raupatu Claims Settlement Act 1995.

6 British Nationality Act 4 Geo II, c 21 (1736) 13 Geo III, c 21 (1772), s 2.

7 The Queen v 7 Named Accused, above n 1, para 24 Judgment of Full Court.

8 Joyce v Director of Public Prosecutions [1946] AC 347 (HC). 
held no such passports offering them protection and if the act of burning the Bounty was not sufficient an act to demonstrate the renunciation of the Crown's protection it is difficult to imagine what might be. However, the later descendants of the mutineers, that is the accused in the case before the Pitcairn Supreme Court, did hold British passports, and subsequent actions by Pitcairn Islanders suggested that the islanders had indeed sought protection from the Crown and its assistance from time to time. ${ }^{9}$

Secondly, while the claim that the children took their mothers' nationality rather than their fathers' was probably correct - although the Supreme Court did not address this issue - three further British subjects had arrived on the island after the initial settlement, ${ }^{10}$ thereby continuing British allegiance by their presence and the children they fathered.

Similarly, the Court of Appeal held quite clearly that the mutineers never ceased to be British subjects. ${ }^{11}$ As British subjects, therefore, Pitcairn Islanders might be subject to British rules. The reason for this lies in the oft-cited statement of English law expounded by Blackstone that "[i]f an uninhabited country be di[s]covered and planted by Engli[s]h [s]ubjects, all the Engli[s]h laws then in being, which are the birthright of every [s]ubject, are immediately there in force."12

Further questions were raised however. Even if the mutineers who first settled on Pitcairn were British subjects, was Pitcairn a British territory, and if so what were the consequences of that?

\section{B The Nature of British Control over Pitcairn}

As indicated above, the Privy Council held that Pitcairn was a "British possession". This meant that Pitcairn was a colony or overseas territory of the United Kingdom. The mere occupation of islands by British subjects does not necessarily make that island a British possession.

Halsbury offers two possible categories for colonies: settled or conquered/ceded. Settlement occurs "if there was no population or no form of government considered civilised and recognised in international law". ${ }^{13}$ If Pitcairn was a British territory (a term now used in preference to colony) then it had become so by settlement not conquest, there being no indigenous people there to

9 Under the British Overseas Territories Act 2002, British Dependent Territories' citizens became British overseas territories citizens. Pitcairn Islands is one of fourteen British overseas territories. The islanders are therefore British citizens but do not have a right of abode in the United Kingdom.

10 These were John Buffet and John Evans who arrived in 1823 and George Nobbs who arrived in 1828.

11 The Queen v 7 Named Accused [2004] PNCA 1, para 35 Judgment of the Court.

12 William Blackstone Commentaries on the Laws of England (Classics of English Legal History in the Modern Era series, Garland, New York, London, 1978) Vol 1, Section IV, 108.

13 Halsbury's Laws of England (4 ed, LexisNexis, London, 2003) Vol 6 para 800. 
conquer. ${ }^{14}$ Such settlement would usually require the country to be settled in the name of the Crown. Clearly the mutineers had not done this. Indeed no one knew they were there for several years.

Although distinguishable on its facts, the case of $R$ (Bancoult) $v$ Secretary of State for Foreign and Commonwealth Affairs, concerning the Chagos Islands, suggests that where there is an issue as to how a territory is acquired that issue is to be determined by reference to "the time the territory ... becomes subject to the Queen's dominion". ${ }^{15}$ The Crown never claimed ownership of the land of Pitcairn, nor did it make grants of that land. Its exercise of political sovereignty over the island was initially weak and it is unclear whether the actions of early naval officers in assisting Pitcairn Islanders with law and order issues were done under any higher authority. It was not therefore certain when the island first came under the Queen's dominium.

When the Pitcairn case reached the Privy Council, it was held that whatever "the inclinations of its people may have been, it is unthinkable that the Judicial Committee of Her Majesty's Privy Council would not accept an executive statement affirming it to be part of the territory of the Crown." 16 The status of Pitcairn was therefore to be determined not by the actions of the Pitcairn Islanders or a consideration of its history but a statement of the executive. In reaching this decision the Privy Council adopted the reasoning advocated by Atkin LJ in The Fagernes case, where he stated: ${ }^{17}$

What is the territory of the Crown is a matter of which the Court takes judicial notice. The Court has, therefore to inform itself from the best material available; and on such a matter it may be its duty to obtain its information from the appropriate department of Government. Any definite statement from the proper representative of the Crown as to the territory of the Crown must be treated as conclusive.

While the Privy Council did indicate that there are limits to this doctrine of accepting as conclusive statements from the executive, it considered that Pitcairn fell squarely within the doctrine so that it was unnecessary to critically examine the assertion by the Crown's representative. Lord Woolf, however, in an interesting obiter statement indicated that where there are any doubts about an executive statement that a country was a territory of the Crown "it would be necessary to re-

14 Before the Privy Council the argument was raised - and quickly dismissed - that the British Crown acquired Pitcairn by cession: Christian and Others $v$ The Queen, above n 4, para 11 Lord Hoffmann.

$15 R$ (Bancoult) $v$ Secretary of State for Foreign and Commonwealth Affairs [2001] 1 QB 1067, 1102 Laws LJ.

16 Christian and Others $v$ The Queen, above n 4, para 10 Lord Hoffmann.

17 Coast Lines Ltd v Society Nazionale di Navigazione of Genoa (The Fagernes) [1927] P 311, 324 (EWCA) Atkin LJ. 
examine the authorities ... which support the contention that an act of state is to be regarded as conclusive on issues as to the status of alleged British possessions overseas."18

So how did the representative of the Crown, the Secretary of State, arrive at this "conclusive" statement?

\section{Asserting sovereignty over Pitcairn}

Although there is archaeological evidence that Pitcairn had been previously settled, when the mutineers arrived it was terra nullius. The mutineers certainly did not settle the island as representatives of the British Crown. ${ }^{19}$ There was not, either then or in the years that immediately followed, any formal act or legislation which brought Pitcairn Islands under the sovereignty of the Crown. ${ }^{20}$

The early years of the history of Pitcairn were marked by lawlessness, but under the leadership of the last surviving mutineer, John Adams, order seems to have been restored. ${ }^{21}$ In 1838 Captain Eliot of HMS Fly, ${ }^{22}$ at the islanders' request, drew up a written constitution and code of laws "selected from those already in force", ${ }^{23}$ suggesting that even at this early stage the islanders had their own system of law. The new constitution included the novel provisions of compulsory education for all children and universal suffrage. ${ }^{24}$ Further revised and more extensive constitutions followed. ${ }^{25}$ Although an officer of Her Majesty's Royal Navy, it is not at all clear that Captain Eliot

18 Christian and Others v The Queen, above n 4, para 33 Lord Woolf.

19 The Queen v 7 Named Accused, above n 1, paras 67-68 Judgment of Full Court.

20 There were for example no Crown grants of land, which distinguished the case of the Pitcairn Islands from the British Honduras: Attorney-General of British Honduras v Bristow (1880-1881) LR 6 App Cas 143 (PC). Indeed for eighteen years no one knew that the Pitcairn Islands were settled by the mutineers.

21 The government web site for Pitcairn states "Such was his manner that all took pleasure in obeying his example, which he patterned on virtue and piety and regulated by the Church of England's Book of Common Prayer, on Sunday services, family prayers and grace before and after every meal" www.government.pn (accessed 26 April 2006).

22 The correct spelling is uncertain, he is referred to as Elliot ( $R v$ Christian (No 2) [2005] LRC 745, para 54 Judgment of the Court (PNSC)) and Eliot ("Pitcairn's History" www.government.pn (accessed 26 April 2006)).

$23 R v$ Christian (No 2), ibid, para 54 Judgment of the Court. Challenges by visiting American whalers which included threatened violations of the female islanders and the recent experience of government by the dictator Joshua Hill, seem to have prompted this request.

24 D Srivastava "Pitcairn Island" in M Ntumy (ed) South Pacific Island Legal Systems (University of Hawaii Press, Honolulu, 1993) 252, 253.

251852 Admiral Moresby, 1892/3 Captain Rookes. Srivastava, ibid, also mentions changes to the 1838 Constitution in 1864. The 1893 Constitution introduced a parliamentary system with seven elected members with authority to appoint a President, a Vice President, two judges and a secretary. Parliament was to make laws, enforce decisions of the Magistrate's Court and hear appeals against that court's decisions. 
was acting within a particular mandate from the Crown to make rules for Pitcairn or simply responding to an immediate demand by the islanders. The fact that approval by the Admiralty of his actions was sought after the event, together with the fact that there was never any formal notification of sovereignty over the island by the British government, suggests that he may have been acting in an unauthorised manner. Similarly, whether visits by naval vessels were a result of Admiralty instructions or in the nature of opportunist re-victualing stops is unclear. ${ }^{26}$ Nevertheless, the Supreme Court seems to have accepted that Captain Eliot's intervention marked the formal acknowledgment by the Pitcairn islanders of their status as a British possession. ${ }^{27}$ The Court relied on the writing of McLoughlin, a legal advisor to the Governor, whose objectivity and impartiality must be in doubt. Indeed there is some suggestion that Pitcairn Islanders did not consider themselves under the protection of the British monarch at this time because in 1853 a letter was sent to Queen Victoria seeking to be considered a British colony. There is no record of any response to this request although a separate request to move from Pitcairn to Norfolk Islands due to the shortage of land and timber for fuel was acknowledged, and eventually acted on in $1856 .{ }^{28}$

The removal to Norfolk Island disrupted the settlement of Pitcairn but forty-three Pitcairn islanders returned to Pitcairn in $1859 .{ }^{29}$ Indeed during the sojourn of Pitcairn Islanders on Norfolk Island the Governor of New South Wales, who was appointed to legislate for Norfolk Island, was instructed to refrain from making laws for the people of Pitcairn, ${ }^{30}$ reinforcing the idea that these Pitcairn Islanders had their own laws.

26 In the Court of Appeal it was held that "the only inference to be drawn is that they were so acting in accordance with instructions coming from the Admiralty" The Queen $v 7$ Named Accused, above $\mathrm{n}$ 1, para 37 Judgment of Full Court. However the government website for Pitcairn suggests that initial visits were circumstantial and later visits were for re-provisioning and later for tourism when the Panama Canal opened in 1914. The visits of naval warships may have been more due to European rivalry in the Pacific than any paternalistic concern for Pitcairn or its people: "Pitcairn's History" www.government.pn (accessed 26 April 2006).

27 Donald McLoughlin "The Development of the System of Government and Laws of Pitcairn Island from 1791-1971" in Laws of Pitcairn, Henderson, Ducie and Oeno Islands (Government of Pitcairn, Henderson, Ducie and Oeno Islands, Wembley, Western Australia, 1971) 21, referred to in The Queen $v 7$ Named Accused, above n 1, paras 44 and 55 Judgment of Full Court. This is a view shared by Kenneth RobertsWray Commonwealth and Colonial Law (Stevens \& Sons, London, 1966) 908.

28 By this time the population had grown to 150 and food and water were becoming scarce. An earlier removal in 1831 to Tahiti had proved disastrous due to the death of eleven of the islanders from disease, and only lasted six months.

29 The Supreme Court did not accept the argument that the break in residence and the voluntary return of some of the islanders marked an abandonment of the island by British subjects: The Queen $v 7$ Named Accused, above n 1, para 71 Judgment of Full Court.

30 Ibid, para 64 Judgment of the Court. 
In 1887 the British Settlements Act was passed. This Act, which replaced earlier British Settlements Acts of 1843 and 1860, provided for the Crown to set up a constitution in a colony acquired by settlement and also to enact legislation for that colony. ${ }^{31}$ It stated: ${ }^{32}$

It shall be lawful for Her Majesty the Queen in Council to confer on any court in any British Possession any such jurisdiction, civil or criminal, original or appellate, in respect of matters occurring or arising in any British settlement as might be conferred by virtue of this Act upon a court in the settlement, and to make such provisions and regulations as Her Majesty in Council may think fit respecting the exercise of the jurisdiction conferred under this section on any court, ...

This Act and its successor were relied on to justify the making of ordinances for Pitcairn, a practice which has continued to the present day. However questions were raised as to whether the Act could apply to Pitcairn.

A key provision of the Act is its Preamble which states: ${ }^{33}$

[Whereas] divers of Her Majesty's subjects have resorted to and settled in, and may hereafter resort to and settle in, divers places where there is no civilised government, and such settlements have become or may hereafter become possessions of Her Majesty, and it is expedient to repeal and re-enact with amendments the existing Acts enabling her Majesty to provide for such government:

In the region of the Pacific, the 1887 British Settlements Act was given effect by the Pacific Order in Council of March 1893. By giving effect to the Act, the Order extended British jurisdiction to islands in the Pacific Ocean. The 1893 Pacific Order in Council also vested executive and legislative powers in the High Commissioner for the Western Pacific, based in Fiji, enlarging the powers conferred under an earlier Order in Council in 1877.

The 1893 Order applied to those territories by then under British control. ${ }^{34}$ These territories were widely scattered and in most only a rudimentary form of administration was practicable. The 1893 Order also explicitly recognised the independence of these island territories, and the positions of their chiefs and kings. ${ }^{35}$ The geographic extent of Western Pacific Ocean covered by the Order

31 Neither of these earlier Acts were relied on in the Pitcairn proceedings to claim Pitcairn as a British territory.

32 British Settlements Act 1887 (UK), s 4.

33 British Settlements Act 1887 (UK), preamble (emphasis added).

34 Specified as falling under the 1893 Order are: the Friendly Islands, the Navigators' Islands, the Union Islands, the Phoenix Islands, the Ellice Islands, the Gilbert Islands, the Santa Cruz Islands and the Solomon Islands so far as they were not under the jurisdiction of the German Empire.

35 Introduction to the Archive Foreign \& Commonwealth Office (Historical Papers: Documents From The British Archives "The Western Pacific High Commission") www.fco.gov.uk (accessed 10 January 2007). 
was specifically delineated, and initially excluded Pitcairn Islands. ${ }^{36}$ However article 6(2) gave the Secretary of State power to direct that other British settlements in the Pacific should be added. In 1898 the Secretary of State for the Colonies, Joseph Chamberlain, directed that the Order should apply to Pitcairn. ${ }^{37}$ Thus Pitcairn was brought within the potential ambit of the British Settlements Act 1887. The 1893 Order was subsequently replaced by further Orders in Council, the significant ones being those of 1952 and 1970. These Orders provided for ordinances to be made under them for the countries falling within their scope. Such ordinances and laws passed had the force of law and could not be challenged by the courts provided they were intra vires the power conferred by the Order in Council.

Even if Pitcairn Islanders were British subjects it was still necessary to establish that Pitcairn actually fell within the scope of the British Settlements Act. Was Pitcairn, as required by the Preamble, devoid of "civilised government" in 1887 - nearly one hundred years after it had been settled by the mutineers? Again the history of Pitcairn may provide an answer.

By 1887 Pitcairn had had two, if not three, written constitutions; ${ }^{38}$ it had adhered strictly to the Christian faith, first the Church of England and then in the early 1890s converted to the Seventh Day Adventist faith. A system for the administration of justice was in place, the first magistrate having been appointed by democratic process under the 1838 Constitution. By Pacific standards of the time Pitcairn appears to have been quite advanced in its system of rules and government. ${ }^{39}$ In fact the Supreme Court of Pitcairn, hearing the appeal in February 2005, held that "the evidence established that at all relevant times Pitcairn was a developed society". ${ }^{40}$

The Supreme Court addressed this question as follows:

36 North from 140 degrees east longitude by the parallel 12 degrees north latitude to 160 degrees west longitude, thence south to the equator, thence east to 149 degrees 30 ' west longitude. East by the meridian of 149 degrees 30' west longitude. South by the parallel of 30 degrees south latitude. West by the meridian 140 degrees east longitude.

37 The motivation of this specific extension may have been to facilitate the trial of Harry Christian for the murder of his wife and child in 1898: see $R v$ Christian and Others (No 2) above n 22, para 59 Judgment of the Court. In the Court of Appeal it was claimed that this act of the Secretary of State was ultra vires, but this was rejected: The Queen v 7 Named Accused, above n 11, paras 22-28 Judgment of the Court.

38 Those of Eliot (1838), Moresby (1852) and Rookes (1983). See note 25. In the criminal appeal case it is stated that the 1893 Constitution was based on "parliamentary government" $R v$ Christian (No 2), ibid, para 56 Judgment of the Court.

39 For example, Pitcairn's first constitution in 1838 pre-dates other written forms of regulation in the region. In 1852 Cakobau had a constitution written after he had declared himself King of Fiji; in 1850 King Tupou of Tonga had laws written down and in 1876 the King of Niue, Mataio Tuitaga had laws written down.

$40 \quad R v$ Christian (No 2), above n 22, para 1 Judgment of the Court, a view endorsed by the Privy Council. 
We consider that, in order to qualify as 'civilised' a government must have certain characteristics. The most obvious of these would be: the requirement of sovereignty; ${ }^{41}$ the ability to trade with other Governments; and international recognition as being legitimate. Certainly, it would not be one born of a patriarchal community, involving private rules in the sense of those applying in Pitcairn ... 42

There is no authority given for this list of characteristics, no reflection on the colonial arrogance reflected in its perspective of "civilised", nor any consideration of the unique location of Pitcairn Island or the composition and culture of its people. The nature of the sovereignty claimed is not examined. Pitcairn's ability to trade with other governments was indeed limited but due largely to its size and location. When it could, it traded with passing ships.

However, the Supreme Court went on to add that: ${ }^{43}$

even if consideration is given to the nature of civilised government, the limited constitution provided by the Royal Navy, and supervised from time to time ... does not qualify as a civilised government of a kind contemplated by the British Settlement Act 1887.

There is no evidence of what a court sitting in 2005 would consider as amounting to "civilised government" in 1887, but no doubt notions of "civilised" at that time would have been informed by Victorian, European standards. There is some inconsistency in the argument that the mutineers remained British subjects and as such took with them the law of a "civilised" nation, at least to the extent that it was applicable to their new situation, ${ }^{44}$ and their lack of "civilisation". Today in an age more enlightened about cultural differences a different assessment might be expected, especially in the light of criticism of the Eurocentricity and chauvinism of the colonial perspective. ${ }^{45}$

Even if it had been found that Pitcairn had a form of civilised government, this could be sidestepped by interpretative technique as demonstrated by the Supreme Court which stated "in any event the expression 'civilised government' comes from the preamble to the Act and thereby has a very limited role in statutory interpretation". ${ }^{46}$

This is supported by authority and reflects a general rule. There is, however, an exception which applies where the preamble is relevant to interpreting the scope of the legislation and in particular

41 This is really more a matter of international law which the court conceded fell outside its jurisdiction, ibid, para 152 Judgment of the Court; although this did not deter it from ruling on the matter, ibid, para 160.

42 Ibid, para 90 Judgment of the Court.

43 Ibid, para 93 (emphasis added).

44 Blackstone, above n 12, 108.

45 See Philip Joseph Constitutional and Administrative Law in New Zealand (2 ed, Brookers, Wellington, 2001) 50-53.

46 The Queen v 7 Named Accused, above n 11, para 91 Judgment of the Court. 
the right conferred on the Crown. Arguably it is the Preamble to the British Settlements Act which is a key here. The Act is to provide for government where there is no "civilised government". Nevertheless, the Supreme Court was of the view that the preamble of an Act need only be referred to in the case of ambiguity in determining the scope of the right. No such ambiguity was found here. ${ }^{47}$

The Court of Appeal seems to have applied the law rather differently - although with the same conclusion. It accepted that the Preamble was relevant but held that "Pitcairn had no civilised government when the settlement occurred, [therefore] the initial provisions of the preamble applied." ${ }^{48}$ The crucial moment in time therefore, was not the date of application of the British Settlements Act 1887, but a century earlier when the mutineers first landed on an uninhabited island. So whatever measures the Pitcairn islanders had adopted to develop a civilised, well-regulated society by the time the British Settlements Act was extended to the island in 1898 became irrelevant.

\section{Which colonial rules governed Pitcairn?}

A further related question which does not seem to have been clearly addressed was the extent to which the rules governing Pitcairn might be said to be private rules or a system of colonial government. Blackstone suggests that there were three forms for determining the internal or domestic government of colonies: a charter, which conferred the power to make self-regulating subsidiary laws; feudal grants by the Crown to individuals of land over which the feudal owner had subsidiary legislative power; and the exercise of powers conferred on governors under royal commissions. ${ }^{49}$ Only the last could apply to Pitcairn and would have been relevant from 1898 when Pitcairn was specifically brought within the Pacific Order in Council. By this date, as has been indicated, there were a number of regulations, office holders and structures in place which governed life on Pitcairn. Prior to 1898 the only power reserved to British agents was held by visiting captains of Royal Navy ships, who were to deal with serious crimes falling outside the remit of the island magistrate. This arrangement would seem to fall outside Blackstone's categories.

The Court of Appeal rejected the submission that Pitcairn fell outside the British Settlements Act 1887 because it was under a legislature "constituted other than by virtue of this Act". ${ }^{50}$ In reaching this conclusion, the Court of Appeal dismissed the evidence that under the 1838 Constitution Pitcairn had an elected magistrate assisted by a Council of one elected member and one nominated member, and that various rules were in place to maintain order and regulate family

\footnotetext{
47 Ibid, para 93 Judgment of the Court.

48 Ibid, para 36 Judgment of the Court.

49 Blackstone, above n 12, 109.

50 British Settlements Act 1887 (UK), s 6.
} 
matters. It also dismissed the new court structure and parliamentary form of government established under the Rooke Constitution of 1893. Instead the Court of Appeal held that: ${ }^{51}$

[i]t had no legislature in 1898 ... Pitcairn was not competent to make laws ... The adoption of the 1893

Rookes initiated laws were no more than an exercise of common law rights. They did not establish an independent legislature ...

Presumably in referring to the "exercise of common law rights" the Court of Appeal was simply reiterating the view expressed by Blackstone and endorsed by writers such as Roberts-Wray that where British subjects settled in a country which had no organised government prior to settlement, then they carried English law with them so far as this was appropriate for the new settlement. However Roberts-Wray goes on to add "and though the Crown has a constituent power, it cannot make ordinary laws for them". ${ }^{52}$ In the case of unauthorised settlements, such as Pitcairn, ${ }^{53}$ or where the home government is "indifferent or inactive" then, according to Roberts-Wray "settlers have a common law right to set up a body to make such laws as they require and Courts to enforce them". ${ }^{54}$ This would support the claim that Pitcairn was governed by a legislature established outside the British Settlements Act.

Indeed the Court of Appeal seems to have partially accepted this line of reasoning, holding that "settlers can be expected to adopt rules and regulations governing their community where these do not already exist, and that is not in any way inconsistent with the concept of dependency."55

So a colony or settlement can, to a greater or lesser extent, be self-governing but still dependent. It is not clear what form of dependency is envisaged here; neither political nor economic dependency is necessarily incompatible with various forms of self-government. Many of the island nations of the Pacific region are dependent to a greater or lesser extent on countries such as Australia, New Zealand and the United States of America. Indeed, increasing dependency may go hand in hand with the increased intervention in Pacific island affairs by more powerful nations or be integral to relationships of free association. Given the neglect which the United Kingdom had shown toward Pitcairn it might be argued it has been independent rather than dependent for much of its history.

51 The Queen v 7 Named Accused, above n 11, paras 49-51 Judgment of the Court.

52 Roberts-Wray, above n 27, 151.

53 British Honduras and Tristan da Cunha are cited as other examples by Roberts-Wray. In New Zealand settlement also occurred prior to assertion of the Queen's sovereignty and settlers in Wellington had created their own governing body in 1840, before sovereignty over New Zealand was proclaimed.

54 Roberts-Wray, above n 27, 153-154.

55 The Queen v 7 Named Accused, above n 11, para 51 Judgment of the Court. 
A detailed analysis of many of the inconsistencies raised in considering the question of whether Pitcairn was a British settlement was effectively avoided by the Court of Appeal in holding simply that "an assertion by the Crown of jurisdiction over a territory is an act of state, not susceptible to challenge." 56 However, some of the authorities relied on to support this proposition are distinguishable, and therefore of questionable relevance, because they relate to the appropriation of land by the Crown which purported to extinguish native title claims. ${ }^{57}$ As indicated above, the Crown had never claimed or appropriated any land in Pitcairn and in any case the absolute nature of Crown claims to land which purport to extinguish native claims has been challenged in Australia in Mabo v Queensland. ${ }^{58}$ Further, Denning LJ had suggested in Nyali Ltd v Attorney General that the Court should look ${ }^{59}$

at the Orders in Council and other acts of the Crown so as to see what jurisdiction the Crown has in fact exercised; because they are the best guide, indeed they are conclusive, as to the extent of the Crown's jurisdiction.

Arguably there is a distinction between the assertion of jurisdiction over a territory and the practical exercise of that jurisdiction or the effective implementation of that assertion, especially when British interest in and contact with Pitcairn had been at best sporadic and for long periods of time non-existent. Indeed some of the evidence relied on to support British jurisdiction over the island had been of relatively recent date, such as Schedule 6 of the Nationality Act 1981 (as amended by the British Overseas Territories Act 2002) which includes reference to Pitcairn, Henderson, Ducie and Oeno and the dicta of Cooke P in the case of Governor of Pitcairn \& Associated Islands $v$ Sutton. ${ }^{60}$

Despite this rather flimsy evidence, the Court of Appeal held that there was no doubt either as to British sovereignty over the island or the exercise of its jurisdiction over the island. The Court of Appeal also refrained from defining the moment at which Pitcairn became a British possession, relying instead on the notion of a gradual extension of jurisdiction over a territory. ${ }^{61}$

So when was the moment in time when Pitcairn became subject to the British Settlements Act not just in principle but in practice? Under the 1893 Pacific Order in Council, once it was extended to Pitcairn, the High Commissioner could make regulations for Pitcairn pursuant to article 108 of that Order but he could not constitute courts. It would seem therefore that the court structure

56 Ibid, para 12 Judgment of the Court.

57 See Sobhuza II v Miller [1926] AC 518 (PC); Re Southern Rhodesia [1919] AC 211 (PC).

58 Mabo v Queensland (No 2) (1992) 175 CLR 1.

59 Nyali Ltd v Attorney General [1956] 1 QB 1, 15 (EWCA) Denning LJ (emphasis added).

60 Governor of Pitcairn and Associated Islands v Sutton [1995] 1 NZLR 426 (CA) 429-430 Cooke P.

61 Following Attorney General for British Honduras v Bristowe, above n 20. 
established under the Pitcairn Constitution remained in place. Jurisdiction over the crimes of rape and murder were excluded from these courts. In fact it was such a crime that probably motivated the extension of the 1893 Pacific Order in Council to Pitcairn. Harry Christian, descendant of one of the mutineers and forbear of one of the Pitcairn accused, was charged with the murder of his wife. In order to bring him to trial a Chief Police Magistrate from Fiji was sworn in as a judicial Commissioner of the Western Pacific High Commission under the powers conferred by the 1893 Pacific Order in Council. The accused was sentenced to death under English law. This marks 1898 as being a significant moment for bringing Pitcairn under the powers of the Western Pacific High Commission, but did it mark the point at which Pitcairn became effectively governed by the British Settlements Act?

A more significant point in was time in 1904 when the British Consul at Tahiti, Consul Simons, visited Pitcairn and assisted the islanders in drawing up a new constitution which was to be in force until 1940. This established a form of local government, recognised and incorporated the local court system, and allowed for the application of local laws. Only in cases not provided for by these was jurisdiction to be exercised the High Commissioner's Court for the Western Pacific sitting at Pitcairn, as provided for under the Pacific Order in Council 1893. The 1904 Constitution built on existing island structures. It recognised the limits imposed on the High Commissioner for the Western Pacific. It also marks a clear moment at which the High Commissioner, or in this case his representative the British Consul, made laws for Pitcairn. The 1904 Constitution included very clear laws (which were to be of relevance in the Pitcairn trial), including Law 2, which made it an offence to seduce a girl under the age of 14 , and Law 3 , which provided for questions of adultery and rape to be referred to the High Commissioner's court for the Western Pacific. Consequently, no specific substantive laws were made for these crimes and there is no reference in the 1904 Constitution as to what laws would apply. It would seem therefore that British powers under the British Settlements Act were being exercised in 1904. In 1937 a further British representative visited the island and drafted a new legal code of rules of procedure for the court. These were implemented in 1940 as the Pitcairn Government Island Regulations.

It was not until 1952, when the 1893 Order in Council was replaced with a new one, that the prerogative power to constitute courts as well as make laws was conferred on Her Majesty's representative. It appeared therefore that Consul Simons and later representatives had been acting ultra vires prior to 1952. Indeed, in 1950 the Fiji Supreme Court held that the 1940 Regulations were ultra vires the High Commissioner's powers. The new 1952 Pitcairn Order in Council, besides creating the office of Governor of Pitcairn, also empowered that Governor to make laws for the peace, order and good government of Pitcairn and to create courts. This would suggest that it was not until the reissued Pitcairn Island Government Regulations (Ordinance No 2 of 1952) that Pitcairn effectively came under the British Settlements Act (now of 1945). The 1945 Act enlarged the scope of the former 1887 Act by allowed delegation to "any three or more persons with the settlement of all or any of the powers conferred by that Act" or "any specified person or persons or 
authority". ${ }^{62}$ This was to be significant for justifying the trial of the accused in the Pitcairn case by New Zealand judges.

Although the reissued 1940 Regulations put in place a code of law and procedure, as indicated, they did not specify what laws were to apply for those crimes falling outside the jurisdiction of the local courts. These were still to be referred to the High Commissioner's Court for the Western Pacific, which was the Fiji Supreme Court. The applicable substantive law would therefore be whatever was applicable in that jurisdiction. Fiji however was a ceded colony not a settlement, ${ }^{63}$ and according to Blackstone until the laws of a ceded colony were changed by the Crown they remained in place. ${ }^{64}$ This would mean that Fijian customary law governed such matters.

This point seems to have been overlooked in the case of crimes falling outside the jurisdiction of the Pitcairn courts, but in any case became irrelevant once the body of applicable substantive law applying in Pitcairn was enlarged by the Judicature Ordinance 1961. Besides divesting the High Commissioner's Court of jurisdiction and transferring this directly to the Fiji Supreme Court, the 1961 Ordinance, and subsequent similar Ordinances, provided for the law in force in and for England to be applied in Pitcairn. ${ }^{65}$ This meant that any law - whether legislation or the principles of common law and equity, in force at the date of the 1961 Ordinance, could potentially apply to Pitcairn. The effect was to import into Pitcairn any English law still in force at that date, subject to the limitation that such law would only apply to the extent that local circumstances permitted.

In 1966 procedural matters, including criminal jurisdiction for serious crimes - which had been reserved for the Fiji Supreme Court, came within the jurisdiction of the Island Court under the 1966 Justice Ordinance. A further Justice Ordinance of 1970 provided for a Supreme Court of Pitcairn and the appointment of judges to this.

In fact, over twenty years were to elapse before any judges were appointed to the Pitcairn Supreme Court and that was to consider these trials. Potentially, therefore, laws and forum were in place long before these trials to consider a range of criminal (and civil) conduct. Nevertheless, the British government, exercising prerogative powers through its executive on behalf of the Crown, felt it necessary to implement a range of new ordinances to bring the accused to trial. What was

62 British Settlements Act 1945 (UK), s 1.

63 The Colony of Fiji was established by Royal Charter in 1875.

64 Blackstone, above n 12, 108. See also section 35-37 Supreme Court Ordinance 1875 (Fiji).

65 Judicature Ordinance 1961 (UK), ss 7 and 8. Subsequent updating Ordinances were ss 14(1) and (2) of the Judicature Ordinance 1970 (UK) which provided for the application of the common law, rules of equity and the statutes of general application in force in and for England; s 14 of the Judicature Ordinance 1983 which was to the same effect but referred to the common law, rules of equity and the statutes of general application in force in and for England on $1^{\text {st }}$ January 1983; and ss 16(1) and (2) of the Judicature (Courts) Ordinance 2000 which refers to the common law, rules of equity and the statutes of general application in force in and for England "for the time being". 
overlooked was the uncertainty as to whether the law under which the accused was charged was in fact part of the law of Pitcairn.

\section{Was the Act Under Which the Accused were Charged Part of Pitcairn Law?}

Investigations into the charges in the Pitcairn case commenced in early 2000 under the 1996 Criminal Procedure and Investigations Act (UK). The committal proceedings were governed by the Justice Ordinance which applied to all criminal investigations commencing after 1 April 1997.66 The conduct of the preliminary hearings was governed by the Judicature (Courts) Ordinance 2000. All of these laws were among those put in place to facilitate trial of the accused.

The charges themselves were brought under the Sexual Offences Act 1956 (UK). ${ }^{67}$ A crucial question was whether this statute was part of the law of Pitcairn. The Judicature Ordinance 1961 which imported English law into Pitcairn, mentioned above, is not specific: it simply refers to "the law in force in and for England".

Blackstone points out that when British subjects take British law with them to a colony they take with them "only [s]o much of the Engli[s]h law as is applicable to their own [s]ituation and the condition of the infant colony", and that what was admitted and what was rejected had to be ascertained in the first instance by reference to "their own provincial judicature". ${ }^{6}$

Consideration of the local circumstances on the reception of English law is not just limited to the law that the colonists take with them, but is a standard provision in legislation extending English law to colonies. Words to this effect are found in the Judicature (Courts) Ordinance 1999 which states: 69

[t]he common law, the rules of equity and the statutes of general application as in force in and for

England for the time being shall be in force in the Islands - so far only as the local circumstances and the limits of local jurisdiction permit and subject to any existing or future ordinance ...

There are two points here. First, whether a statute is one of general application, and secondly, even if it is, are there local circumstances or limits that curtail or modify its application?

66 This was modelled on the Criminal Procedure and Investigations Act 1996 (UK) Revised Edition 2001.

67 The accused could have been charged under the common law but there were concerns that such charges would be out of time.

68 Blackstone, above n 12, 107-109.

69 Judicature (Courts) Ordinance 1999 (UK), s 16(1), (2) emphasis added. This is the standard approach to the incorporation of British laws into overseas territories. See Roberts-Wray, above n 27, 540-541. 


\section{Did the Sexual Offences Act 1956 apply in Pitcairn?}

According to Roberts-Wray a statute of general application is one "of general relevance to the conditions of other countries and, in particular, not based upon politics or circumstances peculiar to England". ${ }^{70}$ The difficulty is that it is not always clear which statutes fall into this category, especially from the point of view of the recipient colony. Within the United Kingdom it will usually be clear from the legislation whether a statute is to apply solely to England and Wales, and/or to Scotland, and/or to Northern Ireland. Historically considerably less attention has been paid by the legislature to whether a statute passed by the Westminster Parliament should apply to overseas territories. Consequently, until either further legislation is passed stipulating which laws apply, as in New Zealand with the Imperial Laws Act 1988, or a court makes a ruling, there is uncertainty. Further, as pointed out by Angelo, in considering whether a statute is one of general application a court should have regard to the circumstances at the time that law is being made in the United Kingdom. ${ }^{71}$ Consequently, as pointed out by Angelo and Townend, it was unlikely that Pitcairn Islanders would know which United Kingdom laws applied to them as statutes of general application until a test case (this case) made a ruling. ${ }^{72}$ In his oft-quoted but perhaps outdated authority on colonial law, Roberts-Wray expressed the opinion that although the phrase "statutes of general application" would probably be unacceptable today because of its lack of definition, nevertheless "it does not appear to have given the courts serious trouble", a view cited with approval by Lord Hope in the Privy Council. ${ }^{73}$ In fact, the question of whether a statute is one of general application or not, has troubled the courts in the South Pacific region for some time. ${ }^{74}$ Certainly, courts in the region have not been consistent in their understanding or interpretation of the phrase, ${ }^{75}$ and, as pointed out by Angelo and Wright, the applicability of criminal law statutes as statutes of general application has not been a feature of the jurisprudence of the region, including New Zealand. ${ }^{76}$

70 Roberts-Wray, ibid, 556

71 AH Angelo "Pitcairn - the Saga Continues" [2006] NZLJ 249.

72 AH Angelo and Andrew Townend "Pitcairn: a Contemporary Comment" (2003) 1 NZJPIL 229. Lord Hope in the Privy Council makes reference to this article but remained convinced that the Sexual Offences Act 1956 was a statute of general application within the meaning of s 14 of the 1970 Order Christian and Others $v$ The Queen, above n 1, para 77 Lord Hope of Craighead.

73 Ibid, para 76 Lord Hope of Craighead, quoting Roberts-Wray, above n 27, 545.

74 See J Corrin-Care "Colonial Legacies? A Study of Received and Adopted Legislation Applying in the University of the South Pacific Region" (1997) 21 Journal of Pacific Studies 33.

75 Compare for example Freddy Harrisen v John Patrick Holloway (1980-8) 1 VLR 147 (a Vanuatu case) with Indian Printing and Publishing Co v Police (1932) 3 Fiji LR 142 (a Fiji case).

76 AH Angelo and Fran Wright "Pitcairn: Sunset on the Empire?" [2004] NZLJ 431. 


\section{Did local circumstances permit its application?}

The second point is whether there were local circumstances or limits which curtailed or influenced the applicability of the law. One of the arguments raised against the applicability of the Sexual Offences Act 1956 was that at the time it was purported to apply to Pitcairn there was no system of appeals in place, therefore the Act was not suitable to the circumstances of Pitcairn or consistent with the limits of jurisdiction in Pitcairn. ${ }^{77}$ However, the Court of Appeal chose to distinguish the Australian case of Quan Yick v Hinds, ${ }^{78}$ which was cited as authority for this point. In that case the High Court of Australia held that an English statute could not apply because the absence of an appeal procedure at the time meant that the law could not be reasonably applied. The Australian court held that the term "reasonably" should be implied into the importing statute. The Pitcairn Court of Appeal appears to have chosen not to imply such a term into the Pitcairn importing Ordinance. Further, the Court was satisfied that although there was no appeal from the Supreme Court of Pitcairn the Governor had the power to make provision in respect of appeals - even if he did not do so until 2000. The Court of Appeal relied on an argument presented in the Bancoult case justifying the "difference of approach between the developed law of England and the law applicable in the colonies."79 Accepting, it seems, the line of reasoning that: ${ }^{80}$

[w]e should, however, ourselves affront the rule of law if we translated the liberal perceptions of today, even if they have become the warp and weave of our domestic public law, into law binding on established colonial powers in the face of authority that we should do no such thing

to justify the view that: 81

the power to make laws for the peace, order and good government of Pitcairn permits the importation to Pitcairn of laws enabling trial for offences in respect of which there is no right of appeal other than by way of petition to Her Majesty in Council.

The Privy Council held that the case of Quan Yick $v$ Hinds did not establish a general proposition in respect of English criminal law incorporated into other overseas British settlements and that the right of appeal was a question of procedure rather than substantive law. ${ }^{82}$

77 Christian v R (No 2), above n 1, para 52 Judgment of the Court. Section 14(2) of the Judicature Ordinance 1970 limited the extension of "[a]ll the laws of England" to Pitcairn by the words "so far only as the local circumstances and the limits of local jurisdiction permit".

78 Quan Yick $v$ Hinds [1905] 2 CLR 345.

$79 R$ (Bancoult) v Secretary of State for Foreign and Commonwealth Affairs, above n 15, paras 43 and 57 Laws LJ.

Christian v R (No 2), above n 1, para 64 Judgment of the Court.

81 Ibid, para 65 Judgment of the Court.

82 Christian and Others $v$ The Queen above n 1, para 15 Lord Hoffmann. 
It might be thought however that the unique geographical and historical context of Pitcairn, its isolation and the racial mixture of its people warranted more careful consideration as to whether a law made in Britain in a very different environment was simply transferable. Indeed Lord Hope in the Privy Council refers to written comments of the Acting Governor made in May 2000 highlighting the remoteness of the island, not just geographically, but from civil authority. ${ }^{83}$ This together with the view of Lord Denning in Nyali Ltd $v$ Attorney-General that: ${ }^{84}$

[t]his qualification [that imported law should only apply in so far as local circumstances permit] was a wise provision, and that it should be liberally construed as a recognition that the common law cannot be applied in a foreign land without considerable qualification

raises the question of whether the local circumstances of Pitcairn were sufficiently considered, particularly given the nature of the crimes with which the accused were charged, the social context in which these were considered and the length of time that had passed since they were committed.

As Trenwith points out "different cultures and societies have varying degrees of norms and taboos relating to this area (sexual conduct)" 85 and that the Pitcairn Islanders should be judged in the context of Pitcairn culture and custom not that of New Zealanders living in Auckland. Pitcairn Islanders have their own language, Pitkern, and are of Polynesian/Anglo descent. Their psyche is that of islanders and their isolation is one of the facets of their identity. ${ }^{86}$ Dr Lissant Bolton of the British Museum, who has undertaken a number of field research projects in the Pacific region, has commented: ${ }^{87}$

[W]hat happens in small communities is that certain ways of behaving become normal. What becomes acceptable has much to do with the leaders of the community. With a claim such as the one about Pitcairn, it could be that people want to justify their behaviour by laying claim to prior practice - and that depends on how they interpret the past. Maybe on Pitcairn there has always been loose sexual practice.

There is the question, therefore, whether Pitcairn customs and the unique Pitcairn cultural identity should have been taken into account in determining the "local circumstances" for the purposes of the applicability of this English statute, or in interpreting the issue of consent, or in

83 Ibid, para 74 Lord Woolf.

84 Nyali Ltd v Attorney-General, above n 59, 16, quoted by Lord Hope, ibid, para 78.

85 Anthony Trenwith "The Empire Strikes Back: Human Rights and the Pitcairn Proceedings" (2003) 7(2) Journal of South Pacific Law Pt VI.

86 Ibid, paras 60-69, referring to Frazer, "Pitcairn Islanders in New Zealand" (Unpublished MA Thesis, University of Otago, Dunedin, 1970).

87 Quoted by Corbett and Stickley "End of a legend as Pitcairn island meets the modern law" (30 June 2001) New Zealand Herald Auckland www.nzherald.co.nz (accessed 26 April 2007). 
considering mitigation of sentence. One of the notable features that emerged during the case was that no cases of rape or sexual abuse had ever been brought to trial in the previous history of Pitcairn. ${ }^{88}$ Although delay in making allegations in such cases is not unusual, in a community as small and isolated as that of Pitcairn it would seem unlikely that much could be kept secret indefinitely. So why was this? One reason may have been a perception - either consciously or subconsciously subscribed to by islanders - that the cohesion and stability of the community unit was more important than the claims of the individual. Another may have been the balance of power within the community. ${ }^{89}$ Once British police were sent to the island in 1999 and thereafter, this balance of power may have changed.

Perhaps the real reason for choosing to reject any local circumstances which might prevent the application of the Sexual Offences Act to Pitcairn is suggested in the opinion of Lord Hope, who, following the view of the Acting Governor, accepted that prosecution had been undertaken to "root out" a "line of offending that had been revealed [to be] a cultural trait". 90

\section{Were there considerations of local jurisdiction which limited application?}

Blackstone advised that in ascertaining what English law was admitted and what restricted by colonists, reference should be had to "their own provincial judicature". This might be taken to mean not only the local courts but also the local laws or legal system.

As has been indicated above, prior to the active exercise of British jurisdiction Pitcairn had a body of laws in place which was subsequently enlarged. The 1966 Justice Ordinance which conferred jurisdiction in criminal matters on the Island Court provided in section 88 that "any male person who shall have carnal knowledge of any female child of or over the age of twelve years shall be guilty of an offence and liable to imprisonment for one hundred days."

Clearly this only applied to a limited class of sexual abuse, and would not apply to abuse of children under the age of twelve and possibly, although this is not so clear, to a female person who was considered to be no longer be a child. ${ }^{91}$ Other offences would therefore fall either under general

88 In the course of its judgment the Supreme Court hearing the criminal appeal referred to the minutes of a local Council meeting held on Pitcairn at which the Pastor "stressed the importance of the parents guarding their young girls from acting free with the boys especially running around with the boys at various places on the island": $R \vee$ Christian, above $\mathrm{n} 22$, para 103 judgment of the Court. While such a warning might be given in any community with young sexually active people it suggests that permissive behaviour was not unknown on Pitcairn.

89 A small insight into Pitcairn society is provided by the appeal of Carlisle Terry Young considered by the Court of Appeal in Christian v R (No 2), above n 1, paras 168-183 Judgment of the Court.

90 Christian and Others $v$ The Queen, above n 1, paras 74-75 Lord Hope of Craighead.

91 In 1997 the Government Advisor Leon Salt indicated that the age of consent on Pitcairn was 16 (under British law) and that "British law applied to females under 12; s 88 (Pitcairn law) applied to females between 12 and 16" $R v$ Christian (No 2), above n 22, para 104 judgment of the Court. 
principles of common law or statutes of general application as provided for in the 1961 Judicature Ordinance. ${ }^{92}$ This seems to be confirmed by evidence considered in the Supreme Court of a letter written by Commissioner Reid Cowell in 1965 to the then Island Magistrate noting that "if any male person should have carnal knowledge of a female child under the age of 12 years, that male person would be liable to be prosecuted under the English law of rape". ${ }^{93}$ However section 88 of the 1966 Ordinance seems to have been the only law under which prosecutions had ever been brought. ${ }^{94}$

Indeed, in the appeal to the Supreme Court in May 2005, a review of offences referred to the various courts which had historically had jurisdiction to consider them, failed to reveal any cases of rape or sexual assault. ${ }^{95}$ Thus it appears that no matters, including rape and serious sexual assault, which originally fell outside the jurisdiction of the Island Court, were tried in the period 1970 to 1999. If Britain was exercising jurisdiction over the island as a "British possession" perhaps it should have been more active in policing criminal activity.

Before the Court of Appeal it was argued that the 1966 Justice Ordinance amounted to a code covering sexual misconduct and that therefore the Sexual Offences Act 1956 did not apply because it was not specifically incorporated. This claim was supported by reliance on other sections which could be used to deal with sexual misconduct, and which could be taken to include indecent assault. ${ }^{96}$ The Court of Appeal rejected this argument, holding that indecent assault was a separate form of assault not covered by the 1966 Justice Ordinance. Therefore the Sexual Offences Act 1956 applied, if not in whole, at least in part.

\section{In order to be applicable should the law be known?}

Even if a statute was notionally of general application, or parts of it were of general application, it is unlikely, certainly until recent years, that it would have been possible for Pitcairn Islanders to access the many potentially applicable laws. Indeed this aspect was acknowledged by the Privy Council. While the common law operates on the basis that ignorance of the law is "no excuse", the assumption that individuals know the law is premised on the fact that they and their advisors "should have access to [the law] in authentic form". ${ }^{97}$ This is a matter which has received close

92 See Angelo and Wright, above n 76, 431.

$93 \quad R v$ Christian (No 2), above n 22, para 79 judgment of the Court.

94 There was evidence that prosecutions had been brought in 1955 and as late as 1999.

95 In 1940 the Pitcairn Island Government Regulations appointed the Fiji Supreme Court as a Court of Appeal for Pitcairn Islands, but there was no reference to rape or sexual assault in the 1940 regulations.

96 Notably s 89 - indecent behaviour in a public place; s 89 - adultery; s 90 - unmarried cohabitation and s 82 - assault including aggravated assault.

$97 R(L) v$ Secretary of State for the Home Department [2003] 1 All ER 1062, 1069 (EWCA) Lord Phillips. 
analysis by Wright. ${ }^{98}$ In the course of the criminal trials, the Supreme Court was satisfied that the Islanders knew sufficiently well that the law, notably that English law, would apply where there was no other applicable Pitcairn Islands law. This may seem a common sense approach. Certainly it is likely that Pitcairn Islanders, however remote geographically, were not so cut off from the world as to be unaware that non-consensual sexual intercourse was a crime, even their religious learning would have informed them of that. The crucial point, certainly from a human rights point of view, is whether the accused were sufficiently aware of the elements which constituted the crime with which they were charged? As Wright points out, even if Pitcairn Islanders had access to a lawyer in New Zealand (5,300 km to the west), that lawyer might not easily be able to access either the Pitcairn Ordinances, which state which English laws apply at what moment in time, nor might they have access to historical legal documents, bearing in mind in this particular case the alleged offences had taken place over a forty year period. Indeed it is evident from the materials disclosed after the criminal trials and which were relied on in the Supreme Court that much information was not even in the local public domain because it was confined to letters, telegrams and Gazettes published in Fiji. ${ }^{99}$

The issue of non-publication was taken up by the Court of Appeal. Article 5(3) of the 1970 Pitcairn Order required that "[a]ll laws made by the Governor in exercise of the powers conferred by this Order shall be published in such manner and at such place or places in the Islands as the Governor may think fit."100

The main ground for the criminal appeal was that "the English law under which they were charged [that is the Sexual Offences Act 1956] ... was not in force on Pitcairn during the period of the alleged offending." 101

The Court of Appeal interpreted Article 5(3) of the 1970 Pitcairn Order to mean that separate publication of each English law was not required. The various Ordinances which declared English laws of general application to apply to Pitcairn were sufficient, even where these applied retrospectively. The Court of Appeal was satisfied therefore that in the absence of a specific local law, the "common law", including unspecified statutes of general application, was sufficiently published in Pitcairn. All that the Governor had to do to comply with Article 5(3) was to make the requisite general Ordinances. The Court of Appeal did not accept that the Governor had to address his mind to which laws were appropriate to the local context. The law-making powers conferred on colonial authorities under the broad umbrella of "peace, order and good government" did not require

98 Fran Wright "Pitcairn - the Saga Continues" [2005] NZLJ 295, 296.

$99 R v$ Christian (No 2), above $\mathrm{n} 22$, para 88 Judgment of the Court.

100 A similar provision was made in the previous 1952 Order which would have covered the relevant period for the Sexual Offences Act.

101 Christian v R (No 2), above n 1, para 7 Judgment of the Court. 
this. Moreover the traditions of colonial governance supported this. ${ }^{102}$ Similarly the Privy Council found that the words "statutes of general application" in section 14(1) of the 1970 Ordinance, which replaced the 1961 Ordinance and operated retrospectively, incorporated not only written law but also the rules of common law and equity.

However in the Supreme Court it was acknowledged that ${ }^{103}$

at no time during the currency of the accused's offending was English law itself published on the islands.

There was no despatch of statutes, legal texts or such compendium publications as Halsbury's Laws of

England...

Further, the Sexual Offences Act 1956 was never expressly extended to Pitcairn. It was not until 2004 that the Supreme Court ruled that this Act applied as a statute of general application. This, as pointed out by Angelo and Townend, is an act of judicial legislation and offends a fundamental principle that "there should be no crime without a law and that a person should not be punished for an act which was not criminal at the time of its commission". ${ }^{104}$ In considering the appeal against criminal conviction the Court of Appeal rejected this argument, holding that "there can be no question but that the 1956 Act is a statute of general application" and that to suggest that each English statute required specific adoption would be contrary to the general provisions of the Ordinances. ${ }^{105}$

The Supreme Court relied on a number of examples where Pitcairn Islanders had sought information about legal matters to demonstrate that Pitcairn Islanders had adequate access to the law. ${ }^{106}$ Most of these examples were of a minor nature but could equally be seen as demonstrating that Pitcairn Islanders were ignorant of the law on a range of matters.

Indeed, the Privy Council held on this question that "ignorance of the law is no excuse ... could not apply where there was no provision ... for the publication or any other provision designed to enable a man by appropriate inquiry to find out what 'the law' is." 107

Much of the case law relied on by the Public Prosecutor predates the United Kingdom's commitment to the European Convention on Human Rights. Also the Privy Council's ruling in Lim

102 Colonial Laws Validity Act 1865 (UK).

$103 R v$ Christian (No 2), above n 22, para 95 Judgment of the Court.

104 Angelo and Wright, above n 76, 432.

105 Christian $v R$ (No 2), above n 1, para 48 Judgment of the Court. There is oblique reference to "some academic writing" and the observation that this was not "advanced in any substantive way before us" (para 50).

$106 R v$ Christian (No 2), above no 22, paras 141-147Judgment of the Court.

107 Lim Chin Aik v R [1963] AC 160, 171 (PC) Lord Evershed for the Court. 
Chin Aik (quoted above) predates the United Kingdom's own Human Rights Act 1998, which imposes on courts a duty to give effect to the provisions of the Convention. It might be argued that the State and its representatives now have a greater responsibility to publicise laws which criminalise certain activities than hitherto, and to ensure that Article 7 of the Convention, which safeguards individuals from being held guilty of offences due to conduct which was not criminal at the time of its commission, is not breached. Today courts are more likely to hold that the law must be both accessible (in its authentic form) and foreseeable. ${ }^{108}$

The Supreme Court, however, was content that ${ }^{109}$

[t]he law demands not that citizens have express awareness of the content of the law, nor that the law is promulgated to that extent, but that the law needs to be accessible in order that people can regulate their conduct by it.

The Court of Appeal was unsure whether accessibility through a government agency would be sufficient but was persuaded that in a general sense the appellants were "sufficiently aware of the unlawfulness of their conduct and its consequence". ${ }^{110}$

The question of sufficient publication and awareness was a key issue in the Privy Council's decision on whether or not there had been an abuse of process. Referring to the case of $R v$ Latif, ${ }^{111}$ the Privy Council accepted that a court had discretion to stay proceedings if the integrity of the criminal justice system was in question due to an abuse of process mounting to "an affront to the public conscience". ${ }^{112}$ Had the law not been published, and therefore could not reasonably be known by the accused, this would point to an abuse of process justifying a stay of prosecution. In the Committee's advice, delivered by Lord Hoffmann, the Privy Council expressed itself satisfied that the Supreme Court and the Court of Appeal of Pitcairn had exercised their discretion appropriately in balancing the public interest in bringing criminals to justice with the need to avoid giving the impression that the end justifies the means. ${ }^{113}$ Whether this was "public interest" of the victims, the Pitcairn public, the New Zealand public or others was not clarified.

$108 R$ (on the application of $L$ ) $v$ Secretary of State for the Home Department, above n 97, 1069 Lord Phillips MR.

$109 R v$ Christian (No 2), above n 22, para 168 Judgment of the Court.

110 Christian v R (No 2), above n 1, para 118 Judgment of the Court.

111 Regina $v$ Latif [1996] 1 WLR 104 (HC).

112 Christian and Others v The Queen, above n 1, para 19 Lord Hofmann.

113 Ibid, paras 19 and 24 Lord Hoffman. 
Nevertheless the question of publication and knowledge troubled Lord Woolf and Lord Hope, both of whom gave separate opinions. Lord Woolf pointed out that: ${ }^{114}$

it is a requirement of almost every modern system of criminal law, that persons who are intended to be bound by a criminal statute must first be given either actual or at least constructive notice of what the law requires. This is a requirement of the rule of law ...

His Lordship was however more easily persuaded than Lord Hope that there had been sufficient publication and knowledge on the part of the accused. Lord Hope was not convinced that there had been sufficient publication of the Sexual Offences Act 1956 under which the charges were brought. He found that: ${ }^{115}$

no steps were taken to bring to the notice of the Island's Council or its inhabitants ... any of the laws of England that might be invoked on Pitcairn to deal with any serious criminal matter not covered by the [Justice] Ordinance [1966].

Indeed the only way in which Lord Hope could persuade himself that the accused would have been aware of the criminal nature of their conduct was by finding that the Sexual Offences Act 1956 created no new offences but simply incorporated into statute offences already known to the common law. As, following Blackstone, it was presumed that the original Bounty settlers of Pitcairn took the common law with them, the accused were charged with an offence of which they would already be aware. $^{116}$

Even if it was generally known that the 1956 Act applied, was it necessary to know, or have access to advice on, the scope of the relevant sections at the time an offence was committed? The Act has been amended since first passed and it has been subject to varying interpretations by the courts of common law in the United Kingdom. ${ }^{117}$ In fact, clarification of the requirements for the actus reus for rape prior to 1976, when the Sexual Offences Act 1956 was amended, only emerges in 1981 in the case of $R v$ Olugboja. ${ }^{118}$ Prior to this there was lack of certainty as to whether force or

114 Ibid, para 40 Lord Woolf.

115 Ibid, para 70 Lord Hope of Craighead.

116 Had charges been brought under the common law however they may have failed due to the period which had elapsed between commission and charge.

117 Especially in $R v$ Morgan [1976] AC 182 (HL). Angelo and Wright point out that prior to 1976 it was a defence to have a reasonable belief that the woman consented. After 1976 an honest (but not necessarily reasonable) belief in consent was a defence. The definition of rape has also changed - Sexual Offences (Amendment) Act 1976. The constituent elements of rape were raised on appeal - Christian $v$, above $\mathrm{n} 1$, paras 151-167 Judgment of the Court.

118 Rv Olugboja [1981] 3 All ER 443 (EWCA). 
fraud was required. ${ }^{119}$ Given that the offences complained of had taken place over a forty year period the uncertainty as to the constituent elements of the crime was relevant and indeed this question was raised before the Privy Council. ${ }^{120}$ The Privy Council held that force or the threat of force was not a necessary requirement and this was well supported by authorities. On appeal against conviction, the Court of Appeal was satisfied that the trial judges had applied the law correctly and that the accused knew that the complainant(s) were not consenting or were reckless as to whether or not there was consent.

Despite its shaky foundations, therefore, the charges under the Sexual Offences Act 1956 were upheld.

\section{E Conclusion}

The decision of the Privy Council has almost certainly concluded the Pitcairn case. ${ }^{121}$ The accused are now serving sentences in Pitcairn in a newly prison built with British money and staffed by New Zealand prison guards. This conclusion looks at two consequences of the case: those for Pitcairn itself and those for New Zealand.

\section{Consequences for Pitcairn}

While the advocacy of international norms of condemnation of child abuse, sexual abuse and gender abuse have been at the forefront, ${ }^{122}$ perhaps insufficient attention has been paid to the cost to a closely knit, interdependent community where the population is related to victims and perpetrators alike. ${ }^{123}$ The need to foster harmony and co-operation in order to survive may be fundamental to the Pitcairn way of life. Different values may apply and different power structures may prevail in order to ensure this survival. These may offend or be incomprehensible to non-Islanders or ex-Islanders who have become acculturated by different norms. ${ }^{124}$ However in a global environment which

119 As indicated above, this was raised as a separate and new point before the Privy Council, which ruled that force or fraud were not necessary elements of the crime.

120 Christian and Others $v$ The Queen, above n 1, paras 27-28 Lord Hoffmann.

121 Doubt as to whether the ECHR applies to Pitcairn, having never been expressly extended to it, probably precludes an appeal to the European Court of Human Rights. See Sue Farran "Prerogative Rights, Human Rights and Island People: the Pitcairn and Chagos Island Cases" [2007] Public Law 414.

122 Fostered it might be said by some fairly sensational media coverage: see for example Jeanette Winterson "Who's guilty of teenage sex?" (15 May 2001) Guardian London www.guardian.co.uk (accessed 30 March 2007); Stephen d'Antel, "That's what girls are for" (9 May 2001) The Times London 22 www.newsintarchive.co.uk (accessed 30 March 2007).

123 "Sex trial would destroy Pitcairn, says mayor" (9 November 2002) New Zealand Herald Auckland www.nzherald.co.nz (accessed 26 April 2006).

124 The concept of "islandness" as a distinct characteristic has received wide academic acknowledgement. See G Baldacchino "Islands, Island Studies, Island Studies Journal" (2006) 1 Island Studies Journal 1. Note also the United Nations Small Island Developing States' Programme (SIDS); UNESCO's agency: Small Island 
upholds tolerance, multi-culturalism and pluralism, there seems to have been singularly little effort to assess these crimes and their consequences within the context of Pitcairn Island. While some modest alternative approaches, such as an amnesty, were mooted and rejected, there seems to have been very little initiative taken by the Governor or Secretary of State to propose restorative justice measures or community arbitration rather than punitive sanctions. ${ }^{125}$ As Angelo and Townend point out, ${ }^{126}$ such an approach is integral to the local circumstances of the island as under the Foreign Jurisdiction Act courts of British territories in the South Pacific had the power "to promote reconciliation, and encourage and facilitate the settlement in an amicable way of any suit or proceedings pending before them". ${ }^{127}$ Indeed, elsewhere in the Pacific restorative justice is not only being advocated but supported financially by governments such as New Zealand and Australia. ${ }^{128}$

It can be argued that consideration of the unique circumstances of Pitcairn and the damaging impact of the trial procedures have been ignored because, as observed by Paul Treadwell, the legal advisor of the Foreign and Commonwealth Office to the Deputy Governor of Pitcairn, "the public interest required that such serious offences ... should be detected and punished, even though the destruction that might result within the tiny island community seemed incalculable". ${ }^{29}$

Besides the potential social and possibly economic impact on the island there is also the question of Pitcairn's future status.

In 2000 the United Nations declared that 2001 to 2010 would be the Second International Decade for the Eradication of Colonialism. ${ }^{130}$ Various options for self-determination are open to countries which are non-self-governing, including integration, independence or free association. All of these models are found in the Pacific region.

Voice; the Alliance of Small and Island States which is active in the General Assembly; the Small States Forum of the World Bank.

125 Possibly because while these measures might have worked within the small community of Pitcairn there were the considerations of the victims in New Zealand and other accused in Australia and New Zealand, and possibly because the Crown that is the executive in London, wanted the publicity of a trial. It should also be noted that the UK Government was engaged in funding a Child Protection Strategy in the Overseas Territories at the time.

126 Angelo and Townend, above n 72, 241.

127 Foreign Jurisdiction Act 1890 (UK), art 34. See also Judicature (Courts) Ordinance 1999 (Pit), s 15.

128 See for comment S Dinnen, "Building Bridges - Law and Justice Reform in Papua New Guinea" in A Jowitt and T Newton Cain Passage of Change: Law, Society and Governance in the Pacific (Pandanus Books, Canberra, 2003) 277, 292.

129 Emphasis added. Letter of 29 April 2000 referred to in Christian and Others v The Queen, above n 1, para 73 Lord Hope of Craighead.

130 United Nations General Assembly Resolution (8 December 2000) 55/146. 
Prior to the Pitcairn case it might have appeared unclear whether Pitcairn was or was not a nonself-governing country. ${ }^{131}$ Clearly it lies outside the electorate system of the United Kingdom; ${ }^{132}$ it is not subject to the same system of taxation or social security and wages are locally determined. It has a subsistence economy subsidised by the sale of stamps and web domains and is the recipient of a variety of forms of aid, most recently from the European Union. However the extent to which it can be said to have its own language, or be ethnically distinct, despite Polynesian influences, may be questionable. Similarly although it appears that Polynesian customary law may have determined land tenure originally, ${ }^{133}$ today a new system of land tenure under the Land Tenure Reform Ordinance 2001 is being implemented from Auckland. ${ }^{134}$ Also, whereas it is clear from its history that for a long time Pitcairn was governed by its own laws and retains an Island Council which has responsibility for much of the day to day government of the island and its people, it is evident from the case that laws which were not specifically for Pitcairn, but which were statutes of general application, or general prerogative powers under the British Settlement Acts, also applied. ${ }^{135}$ Internationally Pitcairn is listed as one of the British overseas territories which are party to a number of international treaties, including the International Covenant on Civil and Political Rights, ${ }^{136}$ but is not one of the countries for which the United Kingdom claims responsibility for international affairs in respect of the European Convention on Human Rights. ${ }^{137}$

The Pitcairn case however strengthens the status of Pitcairn as a non-self-governing territory which continues to be governed by imperial measures. As such Pitcairn is placed very clearly within the ambit of the United Nations resolution. Yet the consequence of British action over the trials would suggest that the United Kingdom has made the possibility of self-determination even more remote and indeed marks a move away from self-determination and towards compulsive integration. This is in strong contrast to, for example, New Zealand initiatives in respect of small island countries such as Tokelau. The practical measures adopted for these trials may, however, see

131 See Alison Quentin-Baxter "The Problem of Islands" [2000] VUWLR 25 for a suggested list of determining criteria.

132 Fran Wright and AH Angelo "'The Pitcairn Trials Act 2003 (NZ), Ordinance 6 of 2004 (PIT), and the Bounty of the Mutiny" (2005) 21 NZULR 486.

133 See D Srivasta, above n 24.

134 See advice to Pitcairn Islanders at www.government.pn (accessed 21 June 2007).

135 Its current position is summarised by Ryan "Towards Self-Determination: A Self-Government Document for Pitcairn" (2006) 12 Revue Juridique Polynésienne 83, 85.

136 See Overseas Territories Core Human Rights Instruments Ratification Table Human Rights Foreign \& Commonwealth Office at www.fco.gov.uk (accessed 24 May 2007).

137 See Council of Europe "List of the Declaration Made By: United Kingdom" (at 17 October 2007) http://conventions.coe.int (accessed 18 October 2007). 
Pitcairn more closely integrated with New Zealand, its nearest neighbour, than with the United Kingdom in the future.

\section{Consequences for New Zealand}

New Zealand-Pitcairn links have thrived since the early twentieth century when ships on their way to New Zealand via the Panama Canal called in at the island. Since the independence of Fiji in 1970, the Governor of Pitcairn has been located in Wellington. New Zealand currency is used and links with New Zealand are maintained in a variety of ways. ${ }^{138}$ A number of Pitcairners are resident in New Zealand. However, recent events may have cast this relationship in a new mould. Not only have the New Zealand media and New Zealand academics kept the Pitcairn story in the public domain, New Zealand has also become more closely involved in the administration of justice in this British territory. New Zealand lawyers, judges and now prison officers have been called on to play a part. ${ }^{139}$ In 2001 a revised edition of the Laws of Pitcairn, which is to be updated annually, was undertaken by Paul Treadwell, now legal adviser to the governor and himself a New Zealand barrister and solicitor.

The facilitation of the trials through the Pitcairn Trials Act 2002 (NZ), put in place as a consequence of Anglo-New Zealand agreement, has embroiled New Zealand in the affairs and governance of Pitcairn in a new and more formalised way and potentially brings Pitcairn more closely under the vicarious administration of New Zealand. The agreement allows for New Zealand laws to be applied to Pitcairn trials held in New Zealand, for the appointment of New Zealand judges and the support of New Zealand police and prison authorities. ${ }^{140}$

This combination of formal and informal ties places New Zealand in a rather strange relationship with Pitcairn. Unlike other islands in the Pacific such as Cook Islands, Niue, Tokelau or the Ross Dependency, Pitcairn is neither affiliated to New Zealand nor integrated as part of New Zealand, as are the Chatham Islands. ${ }^{141}$ Indeed, the other location of Pitcairn Islanders, Norfolk Island, is a territory of Australia, and has a considerable degree of autonomy. ${ }^{142}$ So what is the status of Pitcairn in respect of New Zealand given that the new Pitcairn-New Zealand relationship

138 For example, various New Zealand service personnel have been deployed to Pitcairn from time to time including teachers and radio technicians, and more recently social welfare counsellors.

139 Despite the labels the Pitcairn Public Prosecutor, the Deputy Public Prosecutor, the Public Defender, the Judges of the Pitcairn Supreme and Appeal Courts were all New Zealanders as were the defence counsel, and the various other officers of the courts. Moreover of all the solicitors admitted to the Pitcairn bar 16 are New Zealanders.

140 The agreement can be found as Schedule 1 to the Pitcairn Trials Act 2002.

141 Angelo "To Be or Not to Be... Integrated, That is the Problem of Islands" (2002) 2 Revue Juridique Polynesiénne 87, 100.

142 Ibid, 99-100. 
does not comfortably fit into existing categories? Does the Pitcairn case mark the first step in a process by which Pitcairn will be brought in line with other Pacific island countries in the Realm of New Zealand?

In the meantime the Pitcairn case has demonstrated the long and enduring reach of imperial government and it might be wondered if New Zealand welcomes the manner in which it has been embroiled in the administration of justice in one of Britain's smallest overseas territories. More pertinently, will New Zealand be able to avoid the charge that is now placed in the position of being an agent for British neo-colonialism in the region? 